\title{
Rare perianal extramammary Paget disease successfully treated using topical Imiquimod therapy
}

\author{
Jéssica Silva dos Santos', Gabriel Alves Bonafé ${ }^{1}$, José Aires Pereira², Danilo Toshio Kanno², \\ Carlos Augusto Real Martinez ${ }^{2}$ and Manoela Marques Ortega ${ }^{1 *}$ (i)
}

\begin{abstract}
Background: Perianal Paget's disease (PPD) is a rare intraepithelial adenocarcinoma of the anal margin. Primary PPD likely represents intra-epithelial neoplasm from an apocrine source, whereas secondary disease may represent "pagetoid" spread from an anorectal malignancy.

Case presentation: Histologic CDX-2 and CK20 are hallmark markers for colorectal-derived Paget's cells. Interestingly, our primary PPD patient presented both positive and no internal malignancy was identified. In addition, a negative CK7 marker was observed in our case in contrast with previously reported. Surgical excision is the standard treatment; however, previous studies have demonstrated good response with Imiquimod 5\% cream in patients with vulval extramammary Paget disease (EMPD). The efficiency of Imiquimod treatment for PPD has not been well described. Our PPD patient was successfully treated using Imiquimod 5\% cream.

Conclusions: This study describes a primary cutaneous PPD patient CDX-2+/CK20+/CK7- without invasion of the dermis and no associated colorectal carcinoma effectively treated using topical Imiquimod therapy, suggesting that Imiquimod might potentially be considered as a first-line treatment for PPD.
\end{abstract}

Keywords: Perianal Paget's disease, Histological markers, Differential diagnosis, Topical Imiquimod therapy

\section{Background}

Paget's disease, described by Sir James Paget in 1874 [1], is classified as mammary and extramammary subgroups. Extramammary Paget's disease (EMPD) is a rare condition that is part of a spectrum of intraepithelial adenocarcinomas characterized by proliferation of apocrine cells called Paget cells, located in the basal layer of the skin and often can reach to the entire epithelium thickness [2]. EMPD incidence age is 50 to 80 with the peak age of incidence being 65 years [2]. EMPD of the vulva is most common accounting for up to $65 \%$ of cases while other areas affected include perianal area, male groin, scrotum, and axillae [2]. Perianal Paget's disease (PPD) is a subgroup of EMPD, which is an uncommon intraepithelial neoplasm. The true incidence of

\footnotetext{
* Correspondence: manoela.ortega@usf.edu.br

${ }^{1}$ Laboratory of Cell and Molecular Tumor Biology and Bioactive Compounds, Department of Postgraduate Program in Health Science, São Francisco University (USF), Avenida São Francisco de Assis, 218, Jardim São José , Bragança Paulista, São Paulo 12916-900, Brazil

Full list of author information is available at the end of the article
}

the disease is difficult to estimate due to its rarity, but it is known to represent less than $1 \%$ of all anal diseases and $6.5 \%$ of all cases of Paget's disease [3]. Although its etiology has never been definitively determined, there are two types of PPD, primary likely represents intra-epithelial neoplasm from an apocrine source, whereas secondary disease may represent "pagetoid" spread from an anorectal malignancy [4].

In Brazil, Tanaka et al. [5] reported 14 cases of EMPD, four of which involved women with disease in the vulvar, groin or perianal areas. Trindade et al. [6] reported a primary Brazilian PPD patient, which presented erythematous, itching and little bleeding. The staging tests were normal, without evidence of metastasis.

Imiquimod is an immune response modulating drug that targets toll-like receptors of dendritic and Langerhans cells, which results in the release of multiple cytokines and can directly induce apoptosis of transformed epithelial cells [7]. Imiquimod is a drug of choice for

(c) The Author(s). 2018 Open Access This article is distributed under the terms of the Creative Commons Attribution 4.0 International License (http://creativecommons.org/licenses/by/4.0/), which permits unrestricted use, distribution, and reproduction in any medium, provided you give appropriate credit to the original author(s) and the source, provide a link to the Creative Commons license, and indicate if changes were made. The Creative Commons Public Domain Dedication waiver (http://creativecommons.org/publicdomain/zero/1.0/) applies to the data made available in this article, unless otherwise stated. 
genital warts, vulvar and vaginal intraepithelial neoplasia, and actinic keratosis [8], and it has emerged as a promising drug for the treatment of vulvar and scrotal EMPD [9-11]. However, the exact statistics for PPD treatment efficiency with Imiquimod have not been well described.

The aim of this study was to describe a case of PPD in Brazil, and the effectiveness of topical Imiquimod therapy.

\section{Case presentation}

This study was conducted according to the Declaration of Helsinki, and was approved by the local institutional review board guidelines (number: 54306316.4.0000.5514).

The patient, a 66-year-old Brazilian male sought the Coloproctology Division at USF, Bragança Paulista, São Paulo, Brazil due to a complaint of an anal lump for 3 years, and fistula with absolute hyperemia and decreased caliber of the stool accompanied by increased constipation with occasional rectum bleeding. The colonoscopy showed the presence of intense perianal rash with xeroderma, peeling skin, warty lesions and a severe stenosis of the anal orifice (Fig. 1a). Also, no changes in the rectal mucosa and absence of polyps in the colon were observed.

Perianal surgical biopsies were performed with segments of skin resection and subcutaneous tissue at areas where there was a lack of skin irregularity and hardened consistency. Large biopsies fragments of four quadrants were removed. Post-treatment biopsies were performed using the same technique. Perianal biopsy showed the atypical Paget cells suggesting PPD or balloon cells melanoma (Fig. 2a). For the differential diagnosis, Melan-A, CDX-2, cytokeratin 20 (CK20), cytokeratin 7 (CK7), p63, and human epidermal growth factor receptor 2 (HER2) immunostaining markers panel was analyzed. Positive staining only for cytokeratin 20 (Fig. 2b) and CDX-2 (Fig. 2c) markers was observed. No PPD diagnosis secondary to a colorectal origin was confirmed. The anal orifice stenosis was treated by sphincterotomy.

Local excision is considered the first-line therapy in PPD cases and most of them requiring also an abdominoperineal amputation of the rectum with a permanent colostomy. The patient refused that option. Then, since there was no dermis invasion and no associated colorectal carcinoma, the PPD treatment choice was Imiquimod 5\% cream for 12 months. Every 4 months a new colonoscopy revealed skin condition improvement (Fig. 1b-d) and perianal biopsy showed no residual PPD (data not shown).

After the first Imiquimod treatment cycle, two more surgical biopsies were performed and a new Imiquimod cycle was prescribed. After 3 months a third biopsy revealed no sign of lesion. The patient is currently being closely followed every 3 months. The patient remains without signs
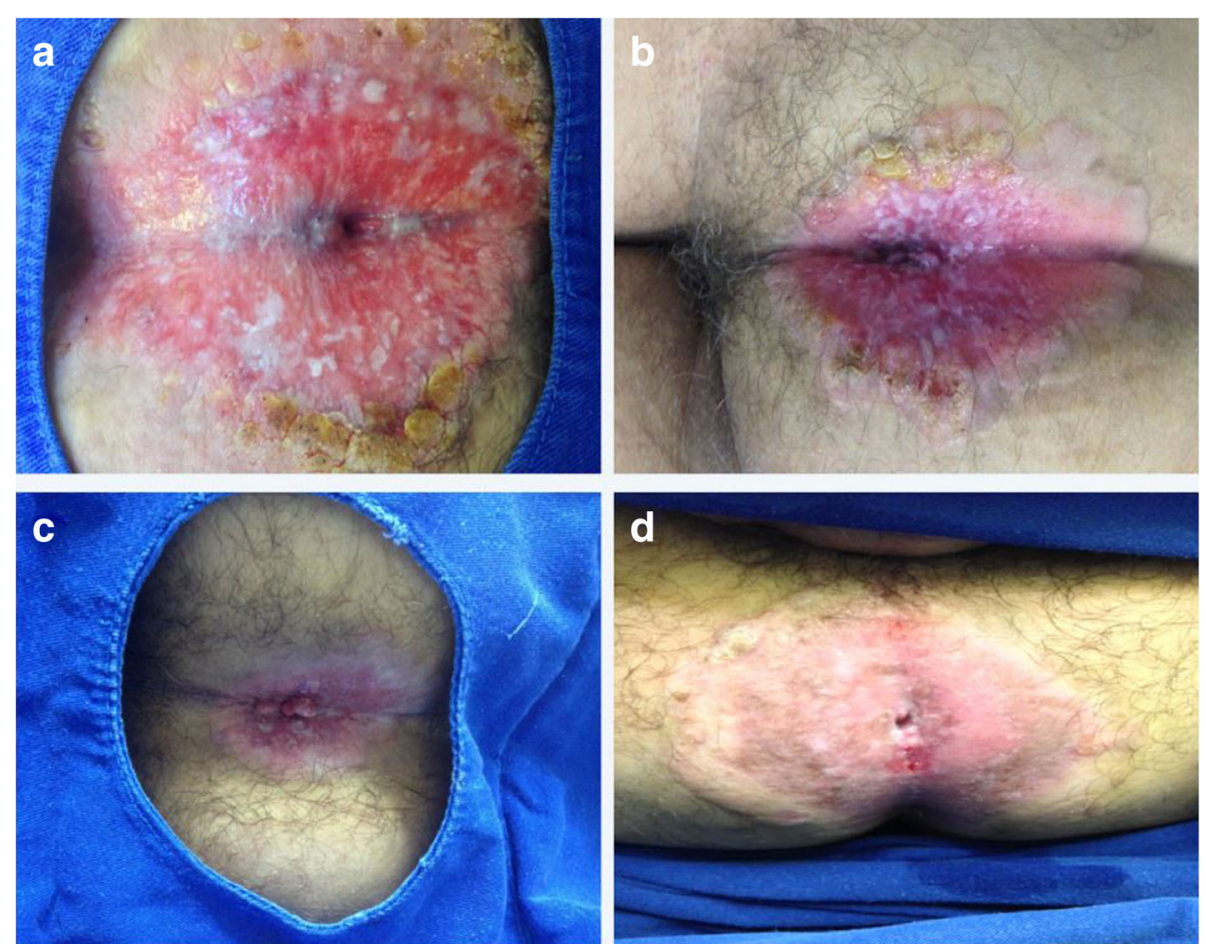

Fig. 1 Colonoscopy examination in the perianal Paget's disease (PPD) patient revealed skin condition improvement (a) Presence of intense perianal rash with xeroderma, peeling skin, warty lesions and a severe stenosis of the anal orifice. $\mathbf{b}$-d After 4,8 and 12 months treatment using Imiquimod 5\% cream, respectively 

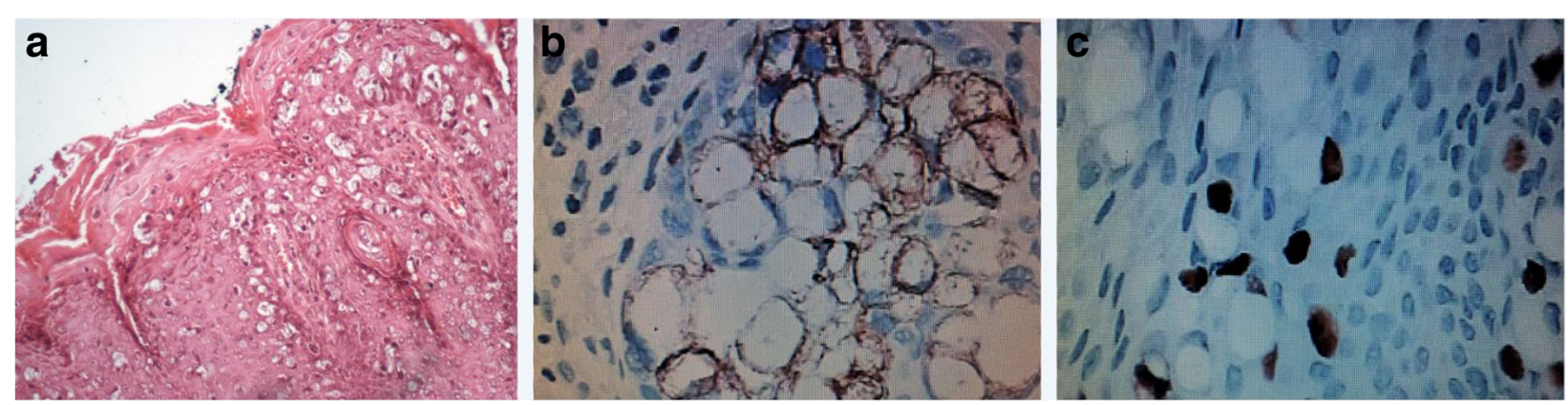

Fig. 2 Histologic Findings of a Case of a Perianal Paget's disease (PPD) (a) PPD diagnostic was obtained by histological examination showing the presence of Paget cells which are larger than the surrounding keratinocytes and have prominent nuclei and moderate amounts of pale cytoplasm (hematoxylin and eosin stain, original magnification $\times 200$ ). b Positive immunostaining for cytokeratin 20 (CD20) (original magnification $\times 400$ ). c Positive immunostaining for CDX-2 (original magnification $\times 400$ )

of recurrence to date. If no lesion is observed, the follow-up may include biopsy from the old perianal lesion once a year and colonoscopy once every 2 years.

It is interestingly to note that patient has presented pain and irritation of the perianal skin during the period of Imiquimod application and the inflammatory process completely improved after the first 45 days with remaining residual local pruritus.

\section{Conclusions}

PPD is categorized into primary cutaneous origin and secondary due to the extension of a visceral malignancy as anorectal or colon. Grow et al. [12] reported a 76\% association of PPD with adjacent or bowel carcinoma. This study describes a primary cutaneous PPD patient without invasion of the dermis and no associated colorectal carcinoma.

Differential diagnoses of PPD include Bowen's disease, contact dermatitis, lichenoid lesions, psoriasis, melanoma, perianal Crohn's involvement, mycosis fungoides, squamous cell carcinoma and tinea cruris [13]. Immunostaining markers may enhance the diagnostic accuracy. CDX-2 and CK20 positive markers have been known as markers for colorectal-derived Paget's cells [14-16]. Interestingly, our primary cutaneous PPD patient presented both markers positive and no internal malignancy was identified. CDX-2 sensitivity is modest and it must be analyzed in conjunction with additional immunostaining markers [17]. The negative CK7 marker was observed in our case. Most of the publications confirm that primary PPD is usually CK7 positive and CK20 negative $[18,19]$, whereas EMPD secondary to colorectal carcinoma is positive for CK7 and CK20 [18].

Melan-2 is the melanocyte differentiation marker, and it is negativity excludes amelanotic melanoma [20]. Overexpression of HER-2 protein is seen in $20-60 \%$ cases of EMPD and signifies poor prognosis often due to deep dermal invasion or metastatic disease [21]. The p63 expression in the epidermis and sebaceous glands is useful to differentiate pagetoid bowels disease from EMPD [22]. Our PPD patient presented both HER and p63 negative confirming no internal malignancies or metastasis.

The primary PPD diagnosis must be established using histological examination showing the presence of Paget cells and different histological markers to establish primary cutaneous origin or secondary internal malignancy.

A wide range of PPD treatment modalities have been previously reported, including surgery [23, 24], abdominoperineal resection [25], radiotherapy [26], and chemo-radiotherapy [27]. Few authors have suggested nonsurgical treatment first. Kobayashi et al. [28] reported the effect of intralesional interferon. Our case was treated using Imiquimod $5 \%$ cream and complete healing without recurrence of PPD was observed. One previous report showed similar results in a long-lasting PPD patient without deep gastrointestinal neoplasia [29]. Recently, another report described the primary local treatment of PPD with Imiquimod 5\% cream over a 16-week period initially resulting in remission prior to lymph node spread at 18 months [19].

The present case corresponds to stage I according to Shutze and Gleysteen classification [30]. Recommendation for stages I and II is a wide local excision [13]; however, Imiquimod was successfully an alternative treatment in our case. Long-term follow-up is required to exclude the recurrence of the disease and development of associated tumors.

In conclusion, this study reports clinical characteristics of this rare disease in a Brazilian patient and suggests the use of a nonsurgical treatment for early-stage PPD.

\section{Abbreviations}

EMPD: Extramammary Paget disease; PPD: Perianal Paget's disease

Availability of data and material

The datasets analysed during the current study are available from the corresponding author on reasonable request. 


\section{Authors' contributions}

JSS, GAB, were postgraduates and contributed to the histopathological details of the manuscript. They contributed towards the preparation of the manuscript. JAP was the histopathologists. CARM: the operating surgeon in charge of the case. DTK, the surgical assistant. MMO, conception, design, and corresponding author. All authors were involved in the revision of the manuscript and have approved the final version.

\section{Ethics approval and consent to participate}

The patient gave informed written consent and the project was in compliance with the Helsinki Declaration and was approved by the local institutional review board guidelines (number: 54306316.4.0000.5514).

\section{Consent for publication}

The authors declare that the patient gave written consent for publication.

\section{Competing interests}

The authors declare that they have no competing interests.

\section{Publisher's Note}

Springer Nature remains neutral with regard to jurisdictional claims in published maps and institutional affiliations.

\section{Author details}

'Laboratory of Cell and Molecular Tumor Biology and Bioactive Compounds, Department of Postgraduate Program in Health Science, São Francisco University (USF), Avenida São Francisco de Assis, 218, Jardim São José , Bragança Paulista, São Paulo 12916-900, Brazil. ${ }^{2}$ Department of Surgery and Proctology, São Francisco University (USF), Bragança Paulista, SP, Brazil.

Received: 10 January 2018 Accepted: 13 September 2018

Published online: 25 September 2018

\section{References}

1. Paget J. On the disease of the mammary gland areola preceding cancer of the mammary gland. St Bartholomew's Hosp Rep. 1874;10:87-9.

2. Lam C, Funaro D. Extramammary Paget's disease: summary of current knowledge. Derm Clin. 2010;(4):807-26.

3. Kyriazanos ID, Stamos NP, Miliadis L, Noussis G, Stoidis CN. Extra-mammary Paget's disease of the perianal region: a review of the literature emphasizing the operative management technique. Surg Oncol. 2011;(2):e61-71.

4. Park JS, Kerner BA. Perianal Paget's disease. Semin Colon Rectal Surg. 2003;14:218-21

5. Tanaka VDA, Sanches JA, Torezan L, Niwa AB, Neto CF. Mammary and extramammary paget's disease: a study of 14 cases and the associated therapeutic difficulties. Clinics (São Paulo). 2009;6:599-606.

6. Trindade ES, Polcheira PA, Basílio DB, Rocha ZN, Rocha Júnior JL, Primo GRP. Doença de Paget invasiva da vulva e região perianal: Relato de Caso. Rev Bras Ginecol Obstet. 2004;(4):329-35.

7. Huang SW, Liu KT, Chang CC, Chen YJ, Wu CY, Tsai JJ, Lu WC, Wang YT, Liu $\mathrm{CM}$, Shieh JJ. Imiquimod simultaneously induces autophagy and apoptosis in human basal cell carcinoma cells. Br J Dermatol. 2010;(2):310-20.

8. Kemeny L, Nagy N. New perspective in immunotherapy: local imiquimod treatment. Orv Hetil. 2010;151:774-83.

9. Fehres CM, Bruijns SC, van Beelen AJ, Kalay H, Ambrosini M, Hooijberg E, Unger WW, Gruijil TD, Van KY. Topical rather than intradermal application of the TLR7 ligand imiquimod leads to human dermal dendritic cell maturation and CD8+ T-cell cross-priming. Eur J Immunol. 2014;8:2415-24.

10. Isik O, Aytac E, Brainard J, Valente MA, Abbas MA, Gorgun E. Perianal Paget's disease: three decades experience of a single institution. Int J Color Dis. 2016;(1):29-34.

11. Kim TH, Chang IH, Kim TH, Lee SY, Myung SC. Extramammary Paget's disease of scrotum treated with radiotherapy. Urology. 2009;2:474-3.

12. Grow JR, Kshirsagar V, Tolentino M. Extramammary perianal Paget's disease: a report of a case. Dis Colon Rectum. 1997;5:436-42.

13. Jankulovski N, Spasevska L, Janevska V, Dukova B. A true epidermotropic apocrine neoplasm in the form of perianal Paget's disease: a case report. J Med Case Rep. 2013;7:162-6.

14. De Nisi MC, D'Amuri A, Toscano M, Lalinga AV, Pirtoli L, Miracco C. Usefulness of CDX2 in the diagnosis of extramammary Paget disease associated with malignancies of intestinal type. Br J Dermatol. 2005;(3):677-9.
15. Zeng HA, Cartun R, Ricci A Jr. Potential diagnostic utility of CDX-2 immunophenotyping in extramammary Paget's disease. Appl Immunohistochem Mol Morphol. 2005;(4):342-6.

16. Ramalingam P, Hart WR, Goldblum JR. Cytokeratin subset immunostaining in rectal adenocarcinoma and normal anal glands. Arch Pathol Lab Med. 2001:8:1074-7.

17. Lora V, Kanitakis J. CDX2 expression in cutaneous metastatic carcinomas and extramammary Paget's disease. Anticancer Res. 2009;12:5033-7.

18. Le Fur R, Mears L, Dannawi Z. A perianal extramammary Paget's disease associated with two well-differentiated invasive intramucosal sigmoid carcinomas, a very rare case: an immunohistochemical and clinical review of extramammary Paget's disease. Ann R Coll Surg Engl 2004; 6:w26-w31.

19. Knight SR, Proby C, Ziyaie D, Carey F, Koch S. Extramammary Paget disease of the perianal region: the potential role of imiquimod in achieving disease control. J Surg Case Rep. 2016;(8):1-3.

20. Kaufmann O, Koch S, Burghardt J, Audring H, Dietel M. Tyrosinase, melan-a, and KBA62 as markers for the immunohistochemical identification of metastatic amelanotic melanomas on paraffin sections. Mod Pathol. 1998;8:740-6.

21. Takahagi S, Noda H, Kamegashira A, Madokoro N, Hori I, Shindo H, Mihara S, Esconder M. Metastatic extramammary Paget's disease treated with paclitaxel and transtuzumab combination chemotherapy. J Dermatol. 2009;(8):457-61.

22. Memezawa A, Okuyama R, Tagami H, Aiba S. P63 constitutes a useful histochemical marker for differentiation of Pagetoid Bowen's disease from Extramammary Paget's disease. Acta Derm Venereol. 2008;6:619-20.

23. Murakami K, Tanimura H, Ishimoto K, Yamaue H, Yamade N, Shimamoto T. Reconstruction with bilateral gluteus maximus myocutaneous rotation flap after wide local excision for perianal extramammary Paget's disease. Report of two cases Dis Colon Rectum. 1996;(2):227-31.

24. Lam DT, Batista O, Weiss EG, Nogueras JJ, Wexner SD. Staged excision and split-thickness skin graft for circumferential perianal Paget's disease. Dis Colon Rectum. 2001;(6):868-70.

25. McCarter MD, Quan SH, Busam K, Paty PP, Wong D, Guillem JG. Long-term outcome of perianal Paget's disease. Dis Colon Rectum. 2003;(5):612-6.

26. Brown RS, Lankester KJ, McCormack M. Radiotherapy for perineal Paget's disease. Clin Oncol. 2002;(4):272-84.

27. Thirlby RC, Hammer CJ Jr, Galagan KA, Travaglini JJ, Picozzi VJ Jr. Perianal Paget's disease: successful treatment with combined chemoradiotherapy. Report of a case. Dis Colon Rectum. 1990;(2):150-2.

28. Kobayashi H, Someda Y, Furukawa M, Chanoki M, Hamada T. Intralesional interferon in the treatment of extramammary Paget's disease. Nihon Hifuka Gakkai Zasshi. 1987;1:1-7.

29. Vereecken P, Awada A, Ghanem G, Marques da Costa C, Larsimont D, Simoens $C$, Mendes $C P$, Hendkisz U. A therapeutic approach to perianal extramammary Paget's disease: topical imiquimod can be useful to prevent or defer surgery. Med Sci Monit. 2007;6:CS75-7.

30. Shutze WP, Gleysteen JJ. Perianal Paget's disease. Classification and review of management: report of two cases. Dis Colon Rectum. 1990;(6):502-7.

Ready to submit your research? Choose BMC and benefit from:

- fast, convenient online submission

- thorough peer review by experienced researchers in your field

- rapid publication on acceptance

- support for research data, including large and complex data types

- gold Open Access which fosters wider collaboration and increased citations

- maximum visibility for your research: over $100 \mathrm{M}$ website views per year

At $\mathrm{BMC}$, research is always in progress.

Learn more biomedcentral.com/submissions 